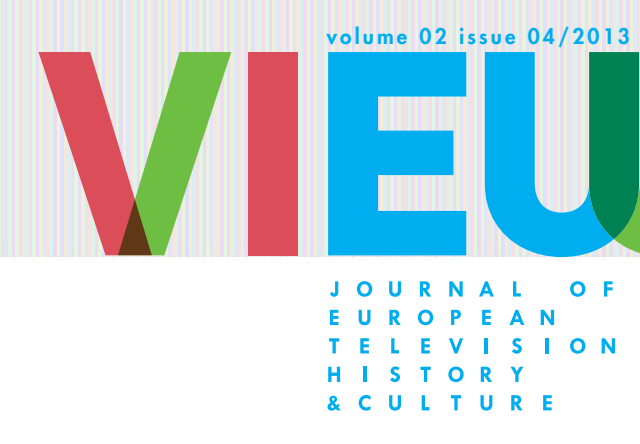

\title{
RATIONAL WIZARDS
}

\section{AUDIENCE INTERPRETERS IN FRENCH TELEVISION}

\author{
Jérôme Bourdon \\ University of Tel Aviv \\ Department of Communication \\ 69978 Tel Aviv \\ Israel \\ Jeromeb@post.tau.ac.il \\ Cécile Méadel \\ Centre de Sociologie de l'Innovation Mines ParisTech - CNRS \\ 60 boulevard Saint-Michel \\ 75006 Paris \\ France \\ cecile.meadel@mines-paristech.fr
}

\begin{abstract}
This paper will tell the story of the small group of people who, in France, have been in charge of the measurement and the appreciation of television audiences, and had to invent audience research. They had to organize it and to communicate its results to 'clients' who depended on it much earlier than usually assumed. These 'clients' were: television managers and professionals, public authorities, and, last but not least, advertisers. The paper will explore how the professional origin and training of measurers has changed over the years: from having an almost literary background to having a formation in sociology and semiology. It gives insights into how the roles of measurers changed from assessing viewers' satisfactions, preferences and viewing habits from 1949 until the mid-60s, to producing audience figures from the mid-60s to the mid 70s and more and more to providing daily, detailed, and quickly produced figures of the audience through audiometers by the mid-80s and afterwards. Despite these changes, the need for effective mediations existed all along.
\end{abstract}

Those mediators - the figures and reports - played several roles. Particularly - and this is true today - they provided channel managers with a source of 'para-democratic legitimacy.' For the 'profession' of measurers, this means that they have always played an important role, as spokespersons of the audience, equipped with an almost magical kind of knowledge: they had the power to 'read' the will and whims of a mysterious, anonymous mass of viewers.

Keywords: Audience History, Audience Measurement, Peoplemeter, French Television.

\section{Introduction}

This article tells the story of little-known professionals whose work has long been perused with no less passion than major prime shows: the people who have been in charge of the measurement and the appreciation of the television audiences, and had to invent audience research, to organize it and to communicate its results.

It is not easy to give a name to this particular trade. We prefer not to talk about audience measurers, as this will be anachronistic: although they were present from the start, audience numbers were not always as central as they are 
today. And although we used the term professionals,' it is best to talk, until the 1980 s, of an occupation: there was no required profile for the people in charge of interpreting the audience and no established organisation. In France, the service in charge of this particular task changed names and attributions several times, before the creation of Médiamétrie, the company responsible for audience measurement in 1985. This company is still at the centre of the market of broadcasting measurement, and also for the Internet, together with a subsidiary of the American Nielsen. ${ }^{1}$ The occupation has changed, but there have always been people in charge of interpreting the will of the public, trying to make them talk and conceive forms of measurement, which would change a lot during sixty years. The public, a 'tyrant' with 'a million heads'2 - to use a phrase of François Mauriac, the French writer who was, for a while, television critic - needed interpreters. We will use the term 'interpreter'3 to refer to this activity. Like interpreters, these professionals had to translate a foreign language into something that television professionals, especially managers and heads of programs, and also public authorities, could understand. Like interpreters, they needed to understand both languages: the professional language and the language of the public. They were also interpreters in the other sense of the word: they played the role of the public for the professional; they transformed the multiple and plural voices of a complicated assembly into a simple discourse.

The term 'rational' in our title does not mean that we stress a process of rationalization, although this can be used as a way to relate how the need for a coherent, quantified assessment of audiences grew within media organizations. ${ }^{4}$ As we will see, some form of rational knowledge and technology has 'always-already' been available for measuring television audiences. The know-how necessary for interpreting audiences changed rapidly, evolving with the history of technology (computing and electronics) and the history of sciences (psychology receded, the part that sociology played was uncertain, and statistics took centre stage, at least a certain form of statistics). We discuss these changes, making no claim about the superiority of any given form of knowledge. We do not contrast intuitions with scientific knowledge. Both have always coexisted. The people able to evaluate the audience have always been credited with some sort of 'magical' competence, for which the metaphor of 'having flair' has been used from the start. But this is always accompanied by some socio-technical arrangements, by some form of knowledge used for giving a voice to the audience (sometimes literally).

The sense of wizardry, of flair, goes back a long way in media history. As Schudson reminded us, it was said of Albert Ochs, one of the early editors of the New York Times: 'Ochs is a crowd, ${ }^{5}$ meaning he had a sense of what the audience preferred. On the other hand, in the history of the mass media, there have always been numbers, surveys, polls, statistics - words whose meaning and use evolved during the period considered. We might recall the straw polls, organized from the early 19th century, in Europe as well as in the US, ${ }^{6}$ with a sophisticated (for the time) technology of collecting and measurement. ' Between 'hard' knowledge and 'soft' intuition, there is no competition, but rather they are complementary to one another. One thing that has changed, though, is that in the beginning both tended to merge completely. The person in charge of content/programmes - the 'connoisseur' of audience tastes - was able to predict, roughly, sales or success. Progressively, the professional mix has become more complex, the wizardry of the content manager relying, more and more, on the technology of the pollster, the measurer. But this function, as we will show, can never be a purely technical one. The specialized audience interpreters are also credited with their own brand(s) of wizardry.

Although the number of audience interpreters has grown, we are talking about a small population, whose numbers are not clear. Who decides that you are a professional of the television audience, then or now? As we will see, their formal education has changed over the years, although a formation in statistics has been considered as a requirement, since

\footnotetext{
1 Josiane Jouet, 'Les dispositifs de construction de l'internaute par les mesures d'audience,' Le Temps des Médias 3, 2004, p. 160-174, at: http:/l www.cairn.info/resume.php?ID ARTICLE=TDM 003 0160, last viewed on December 3, 2013.

2 Mauriac, François, L’Express, 17 septembre 1959, reprint in J. Bourdon, J.M. Frodon (ed.). L'œil critique, le journaliste de télévision, De Boeck/ INA, 2003.

${ }^{3}$ The word 'interpreter' here is strictly a metaphor referring to a professional occupation. It has no connection with the rich lexicon of 'interpretation, interpreting, interpretive,' which has gained much currency in audience studies since the so-called 'ethnographic turn.'

${ }^{4}$ Philip Napoli, The Rationalization of Audience Understanding, Working Paper, 2008, last viewed December 1 st, 2013.

${ }^{5}$ Michael Schudson, Discovering the News. A Social History of American Newspapers, New York, Basic Books, 1978.

${ }^{6}$ Susan Herbst, Numbered voices: How opinion polling has shaped American politics, University of Chicago Press, 1993

${ }^{7}$ Luc Blondiaux, 'Le nouveau régime des opinions,' Mil neuf cent. Revue d'histoire intellectuelle 1, 22, 2004, p. 161-171.
} 
the mid-1970s. Some professionals we will quote or mention, have worked at some point as media planners, such as Dominique Scaglia who moved to Médiamétrie when the company was created. We will focus mostly on people who were directly involved into the interpretation of audiences within television, private companies, and who performed measurements for television broadcasters or for advertisers, advertising agencies and for companies (especially the people working in media buying departments). These people have had to produce assessments of the audience, and this has been the basis of their professional recognition.

This task has changed in many ways, but we can identify three main interrelated trends: quantification, externalization and increased visibility, which allows us to distinguish three different periods.

The first period starts with the 're-birth' of television after World War II. In this period, the relations with radio audiences were important, since they had much influence in early television. Until the mid-seventies, the interpreters worked mostly inside public service broadcasting, in the 'reactor core,' although there were other attempts to measure the audience, especially among advertisers. The institutional interpreters were so close to production that they contributed to it - they contributed particularly to the genre of (listeners' and) viewers' programmes - where letters were usually read on the air, where selected audience members sometimes participated. In this period, the figures were less important; they were just another way to make the audience talk but also - strangely enough for us today - to address the audience. This rather qualitative audience assessment was hardly externalized and remained mostly invisible. The second period runs from the mid-sixties to the mid-eighties: institutional interpretation no longer took place inside public television, but within a service attached to the Prime minister's office, although with much room for manoeuver. Quantity started to matter more, but there was an on-going fight, ultimately lost, to introduce some measurement of quality. Together with increased quantification, an increased externalization occurred as audience measurement was performed for television by private companies. Although those official figures remained in principle confidential, there was a need for figures, which meant that some were leaked while other actors tried to produce their own figures of the audience; in convoluted ways, the visibility of audience figures increased.

The third period, from the mid-eighties to the present, started with deregulation and the rise of the market. Audience interpretation became identified with audience quantification. Figures became the main ways of interpreting the audience. They gained in strength and visibility. The activity was completely externalized: a private company started producing audience figures, chaired by managers with a strong personality who could now talk in the name of the quantified audience. Visibility, however, did not always mean uncontested legitimacy: the activity of audience interpreters came under attack for a variety of reasons, from within the television industry and from outside.

\section{Inside the Reactor Core: From 1949 to the Mid-70s}

After World War II, French television started again in 1949, within a public administration (a public corporation from 1959 onwards), together with radio. From that moment, a specific service was in charge of 'the relations with the audience.' This was a major break as such a service had not existed during the twenty years of existence of radio before World War II, and was not considered by television which has been a small, experimental service between 1935 and 1949. In this first period, the audience was not the product of the activity of interpretation, but a collective of subjects, somewhat mysterious, one would like to know everything about: what they preferred, the rules they wanted to set for their children, the amount of time and money they were willing to devote to radio and TV. ${ }^{8}$ Behaviours and preferences were the main topics of the surveys, together with listening/viewing habits; overall, a much larger set of indices for interpretation than in the third, and contemporary period. 


\subsection{Talking to the Audience / Talking about the Audience}

Roger Veillé, the first person in charge of the audience at the Radio Télévision Française was recruited because of his links with the Resistance. He had a very mixed profile: a teacher of philosophy, an amateur painter, and also very interested in experimental research on sound, which was performed by public radio in a special department called 'Le Club d'essai.' In 1952, he published a book entitled Of Radio and Men ('La Radio et les Hommes') where he strives to expose the complexity behind the activity of listeners, never reducible to figures as their degree of attention and implication in front of the machine (as he calls radio) varies very much. He explains that a social typology of listeners 'could not be made independently of an analysis, as exhaustive as possible, of the content of programs.' ${ }^{9}$ The audience, at that time, could not be detached from the programme. This is not specific of France, but can be found in early audience research in other countries. At the BBC for example, one of the first enquiries on television audience was made to find out their detailed opinions on programs. ${ }^{10}$

Veillé did not start working on audiences right away. He was first appointed head of propaganda, but immediately went to look for something less glamorous, much less coveted and got the job of head of the service of relations with listeners (not yet viewers, although this would be added later). The service was in charge of processing viewers' letters, then considered as the major source of information about the audience, and, of course to claim that the relation with the audience (active by definition) mattered then, rather than the description of the (more passive) audience. His service 'answered all letters,' ${ }^{11}$ although at the end they were pre-formatted answers available to make the job easier. His predecessor explained why the letters were considered to be so important - a judgment Veillé would have agreed with:

Mail was a good recorder of the variations of public opinion, as the listener, who is also the citizen, and the man in the street, wants to give to the station the whole gamut of his/her reasons for discontent or satisfaction. ${ }^{12}$

Moreover, letters were also a secondary tool for programming, used ad hoc, in a rather political manner: 'as soon as the management didn't like a specific guy, unfavourable letters could be used, but I saw people who received tons of insults and it didn't change a thing. ${ }^{\prime 13}$ In the 1970s, according to a director, the first regular ratings (then kept secret) could be used in the same way, to justify the decision to refuse a programme proposal.

Finally, letters were used on the air. After the end of the war Roger Veille did a radio programme of 35 minutes per week (incorporated in a longer variety show at some point) presenting the letters. For this he found it useful to resort to a time honoured practice of newspapers, which published readers' letters. He rewrote some letters to make them more effective, although he 'didn't invent.' A popular Sunday newspaper also published a very popular page with a selection of letters. At any rate, this means that the 'profession' was not totally hidden.

Letters were not the only device available. Until the late sixties, program managers were also eager readers of critiques and reviews. ${ }^{14}$ The audience also had representatives in programme committees (whose role was rather formal, however). The reaction of the audiences in live programmes (notably very popular entertainment shows) was also scrutinized.

There was some quantitative measurement of radio and television audiences, despite the reluctance of most

\footnotetext{
9 Roger Veillé, La Radio et les hommes, Minuit, 1952, p. 33.

10 Stefan Schwarzkopf, 'The politics of enjoyment : competing audience measurement in Britain, 1950-1980,' in Jérôme Bourdon and Cécile Méadel, Television Audiences Across the World. Deconstructing the Ratings Machines, Palgrave Macmillan, 2014.

${ }^{11}$ Roger Veillé, Interview, 3 January 1989.

12 François-Guillaume, Le Courrier des auditeurs. Interdit au moins de 18 ans, Fournier, 1947.

${ }^{13}$ Roger Veillé, Interview, 3 January 1989.

14 Ibid.
} 
producers. This was provided by a commercial company outside the Radiodiffusion-Télévision Française (RTF) and partly paid for by the public corporation. In fact, it should be remembered that France was a rather early user of audience statistics. Jean Stoetzel, a pioneer in that sense, had created the French Institute of Public Opinion (IFOP) in 1938 after a trip to the US. The IFOP would start producing surveys on a regular, commercial basis at the end of the 1940s. Opinion polls were used in marketing and politics, but these received very little publicity outside those circles. American influence was crucial here, either directly or indirectly. This played a part not only for opinion polls, but - with more economic weight - for market research. Stoezel's deputy remembers:

In September 1944 (after the publication of a poll on France's liberation), two Americans and one British walked into my office with a copy of the newspaper where our poll had been published, they told me they had been sent by the High Command of the Allied forces and they suggested that we worked together. ${ }^{15}$

American influence could also be felt at the public broadcaster. Veillé recalls 'educating himself' from the 'loads of books' American advisers had sent to the managers of public broadcasting, which all contained something on polls and surveys.

Like most media professionals, Veillé was sceptical about strictly quantitative appreciations of the audience. He didn't feel such figures were truly needed, as the managers of stations, especially private radio stations, had a fair sense of the volume of their audience, in a kind of intuitive model: ${ }^{16}$ 'they had the pifomètre, ${ }^{17}$ they didn't need polls for that.' He remembered asking them to give a rough distribution of the audience among ten viewers, and discovering they got 'quite close to the polls figures.' He did order some quantitative surveys from private professionals (among them from IFOP), but his bosses 'didn't really care about the results, there were there to deliver official culture ('la culture officielle'). ${ }^{18}$ The phrase 'la culture officielle' referred to high-brow, traditional culture.

\subsection{Interpreting Taste}

The surveys performed by the public broadcasters didn't only aim at understanding viewers' behaviour and taste. They were also conceived as a tool to address the audience, to make viewers and listeners understand that the institution was interested in them. As the Minister of Information (actually in charge or radio and television) explained in 1954 when he was increasing the budget of radio and television: 'What we expect from polls is first of all that they improve our relation with the audience.'19

Veillé was sacked in 1950 because of his supposed affiliation to communism. Jean Oulif, his replacement, continued in the same vein, but slowly moved to a reconfiguration of audience interpretation, less active, more oriented toward the observation of an outside, objectifiable phenomenon. Less literary, more scientific, he also had a better professional network among people busy with media audiences. He kept the job for more than twenty years, which means that he certainly met the Office's expectations. He was a man of mixed competence. Coming also from the Resistance, he had a diploma in chemical engineering..$^{20}$ When he arrived, the service of the relations with listeners employed some ten people. The budget was modest and the vast majority was devoted to subscriptions and the purchase of newspapers; less than $15 \%$ went to surveys. Despite his scientific training, Oulif had little interest in statistics as such. The people he recruited, including Michel Souchon - a Jesuit and sociologist who would later become an audience researcher for public service broadcasting - or sociologists, were not trained in quantitative

\footnotetext{
15 Hélène Riffault, Interview, 4 January 1989.

16 On the role of intuition in the early assessment of audiences in the U.S.A, see Napoli, The Rationalization, p.8

17 A word that can be translated as the 'nose-meter,' again a metaphor based on the sense of smell.

18 Roger Veillé, Interview.

19 CEO Archives, quoted in Cécile Méadel, Quantifier le public. Histoire des mesures d'audience à la radio et à la télévision, Economica, 2010, p.72.

20 Jacques Durand, 'Portrait de Jean Oulif,' Le Temps des Médias 3, 2004, p.138-141.
} 
surveys. For Oulif, the originality of their ideas was the main criterion for choosing them, not their formal education. Oulif still shared this dominant, elitist view of the public, shared by other public service stations of the time, and particularly their model, the BBC. ${ }^{21} \mathrm{He}$ thought that systematic quantitative surveys interested only in the behaviour of viewers treated them not much better than 'guinea pigs.' As the Minister of Information in 1954, he thought that opinion polls could be used for creating a relation with audience members aware they could be questioned some day, which 'made any viewer the virtual subject of a questionnaire [...] Knowing that from one day to the next, he can be questioned on his taste, his preference, the listener can build a distance from his shows, no longer simply ingurgitate them. ${ }^{22}$ This is contrary to the professional ethic of opinion polls and audience measurement (it even was at the time), where subjects are supposed to behave/answer as if they were not being surveyed. It is congruent with the way European directors of programmes considered radio and television at the time: invested with a 'Reithian' mission of changing the public, bringing the best of culture to the citizen-viewer. ${ }^{23}$ On the other hand - and discarding Oulif's axiology - it ironically converges with the most recent sociological analysis of opinion polls, which insists on the fact that the very pervasiveness of opinion polls and surveys has changed the way modern citizens see themselves. ${ }^{24}$

Apart from Oulif, other people were increasingly interested in audiences. The very notion of what an audience (or a public) was, was changing at the time. Marketing was becoming an academic discipline, the National Institute of Statistics and Economic Studies (INSEE) became a major source of knowledge and an important tool for public policy, ${ }^{25}$ while IFOP (to which a competitor, the SOFRES, was added in 1963) became more and more successful with opinion polls, which, thanks largely to their role in the 1965 presidential elections (which played, mutatis mutandis, the role of the 1936 elections in the US), had become a form of public knowledge. Those professionals considered that the pollsters and surveyors of the RTF were amateurs, they could work for them but their own surveys didn't have much value. ${ }^{26}$ Inside the television broadcaster, Oulif and his service suffered from some contempt and also from competition. The mood was changing. In 1964, the service of public relations changed its name and became the service of market surveys ('service des études de marches'), while advertising was still forbidden. The head of this service, Stanislas de Gozdawa - who would become a psychoanalyst - ordered some opinion polls.

In the end, for all its reluctance, Oulif had to produce daily figures. This started in 1964 for major prime time programmes, on a rather shaky basis (even though the need was strong enough for this to be overlooked). It took place via a phone poll with a sample of a few hundred viewers, which was rather biased as by phone it meant that only a small part of the population - the affluent and urban areas - could be reached. In 1970, there were 7,8 lines for 100 inhabitants in France, versus 12,3 for Germany, 15,3 for the UK and 33,3 in the US. ${ }^{27}$

In 1967, the service started ordering continuous audience measurement from IFOP, no longer based on phone surveys but on viewing diaries collected on a weekly basis, so the processing of data took time. Satisfaction indexes were also included, but reading the weekly reports today, it is clear that quantity was what mattered, from the start. On January 1, 1966, the programme Micros et cameras, a weekly magazine on the life of radio and television, invited M. de Gozdawa, together with the director of programmes Philippe Ragueneau to talk about these surveys - an indication that Oulif was not considered as able or important enough. They used the term 'sondages d'opinion' (opinion polls) for referring to the quantitative investigation of the audience - as if still adjusting to new realities with an old lexicon. They uneasily justified the role of quantitative measurement, stating that they took figures into account but that sometimes it takes time for the viewers to understand the value of certain programs. The mission of the ORTF, ${ }^{28}$

\footnotetext{
21 Robert Silvey, 'B.B.C. Audience Research,' in Downham, J., Shankleman, E. and Treasure J. (eds): Readings in Market Research: a Selection of Papers by British Authors, BMRB, 1956, p. 153-174. Stefan Schwarzkopf, The Politics of enjoyment.

22 Jacques Durand, 2004, 'Portrait de Jean Oulif,' 2004, p. 140.

23 Jérôme Bourdon, Du service public à la télé-réalité. Une histoire culturelle des télévisions européennes 1950-2010, De Boecke, 2011, p. 205-

210.

24 Sarah E. Igo, The Averaged American. Surveys, Citizens, and the Making of the Mass Public, Harvard University Press, 2007. For a more critical perspective: Patrick Champagne, Making the People Speak, 'The Use of Public Opinion Polls in Democracy,' Constellations 11 (1), 2004, p. 61-75.

25 Alain Desrosières, The Politics of Large Numbers, Harvard University Press, 1998.

26 Jacques Durand, Interview, 9 April 2002.

27 Pascal Griset, 'Le développement du téléphone en France depuis les années 1950. Politique de recherche et recherche d'une politique,'

Vingtième siècle, 24, p. 41-53, 1989.

28 The RTF has been renamed ORTF (Office de Radiodiffusion et Télévision Française) in a 1964 law.
} 
they remind us, was to shape the taste of the public. It feels as if figures couldn't be ignored although they may have had a bad influence on programming. This will be the dominant tone until the mid-eighties.

Finally, advertising became more and more interested in television. Household equipment was growing, from a rate of $13,1 \%$ in 1969 to $70,4 \%$ in $1970 .{ }^{29}$ In 1957 the regular organization of advertisers - the Centre for the Study of Advertising Media (CESP) - was created. ${ }^{30}$ Its main task was to make a survey of the press audience every few years. This also included television from 1964 onwards, when rumours about the introduction of advertising on television were rife. The CESP was a small organization, but with a crucial role. As one of his former managers told in 1986:

The role of the CESP was once to make an agreement possible on the notions of audience, to help people define the audience. But it didn't have much money, especially for measuring television audience, which is quite costly. ${ }^{31}$

\section{The Ghosts of Quality: from the Mid-Seventies to the Mid-Eighties}

In the 1970s, things changed due to advertising and competition, two factors that are related but should not be equated. In October 1968, advertising had been introduced, after much lobbying by advertisers and much opposition from inside the ORTF. Advertising was initially modest: two minutes per day on the first channel and in 1971 the same amount on the second channel. For many years, until the mid-eighties, advertisers were so eager to get some of the meagre slots offered that they queued (sometimes literally) to buy spaces at almost any price. But advertising grew steadily. ${ }^{32}$ According to Jacques Durand, who was working in the survey department of Publicis, one of the major agencies at the time: 'what changed things for television was the introduction of advertising. ${ }^{33}$ The service changed names once more, becoming the Service of Opinion Surveys (Service des études d'opinion or SEO).

Competition was officially adopted as a programming strategy: in 1970 for the two major newscasts (both scheduled at 20:00) and in 1972 for the two channels at large. Regardless of advertising, competition as such generated much interest for ratings. Indeed, the head of the second channel between 1972 and 1974, Pierre Sabbagh, was appointed to make the audience grow (thus helping the electronic industry to sell more colour sets, as colour had started on the second channel). From the start, he was very much interested in audience figures (and not in quality or interest indexes), as Michel Souchon - who then left his job at the SEO to become Sabbagh's official 'audience man' remembers. ${ }^{34}$

In this context, the SEO was required to work differently. Oulif was sacked and Jacques Durand was appointed chair. He would manage the service for two years, until the reform in 1974, which separated the public broadcaster into seven distinct corporations, including three television channels: TF1, Antenne 2 and France-Régions 3 . His profile was definitely more 'modern.' He had written a PhD thesis on French cinema audiences, had attended Roland Barthes' prestigious seminar on semiotics, and had an M.A. degree in statistics. He was well aware of American sociological work in the field. However he was a particular type of statistician, mastering figures but wary of relying only on a quantitative definition of the audience, something which made him similar to his predecessors.

29 Jérôme Bourdon, Haute Fidélité, Pouvoir et télévision 1935-94, Seuil, 1994, p. 354.

30 Françoise Dupont, 'Les lecteurs de la presse, une audience difficile à mesurer, Le Temps des Médias, 3, 2004, p. 142-151 at http://www. histoiredesmedias.com/Les-lecteurs-de-la-presse-une.html, last viewed September 10, 2013.

${ }^{31}$ Hughes Chavenon, Interview, 3 June 1986.

32 Sylvain Parasie, Et maintenant, une page de pub. Une histoire morale de la publicité à la télévision française. (1968-2008), INA, 2008.

33 Jacques Durand, Interview, 2 April 2002. Jacques Durand has an interesting personal site with some texts regarding the history of audience measurement.

34 Michel Souchon, Interview by Isabelle Veyrat-Masson, Le Temps des Médias, 3, 2004, p.195-205. http://www.cairn.info/resume.php?ID ARTICLE=TDM 0030195 Last viewed December 2, 2013. 
During the time of the hasty 1974 reform, audience measurement was not a central consideration - it was one of the services, which had been forgotten in the first drafts, and about which a late decision had to be made. It was attached to the Prime minister under the name of Centre des études d'opinion (CEO), and more precisely to the office in charge of broadcasting and press policy: the Legal and Technical Information Service, (Service juridique et technique de l'information), which had been created in order to deal with the legal aspects of information policy. Television audiences were clearly a matter to be dealt with by the political echelon, not only by technicians.

CEO's role was crucial for the implementation of a clause of the 1974 law, which obviously wanted to limit the effects of competition by stating that the proceeding of the licence fee - still providing three-quarters of the resources of public broadcasting - should be distributed to the channels according to a quality index. Several formulas were tested, including both appreciations indexes and ratings. But this quest for the right quality index was never satisfactory, certainly not to television professionals and not even to the measurers themselves.

This is partly justifiable by the ambiguous position of the CEO. Directly controlled by the State, it was also producing a type of information considered as crucial, and increasingly so, for a whole private industry (including advertisers and journalists). The role of the service was unclear. Quantitative measurement was what was expected from it, but some of its staff still saw this as part of a wider mission, of knowing the 'opinion' of the public. Durand didn't keep his job but was actually in charge of measurement at the CEO, under the chairmanship of Philippe Ragueneau, a former journalist and head of programming whom we have discussed before. According to Durand, the CEO had much freedom and a very decent budget. ${ }^{35}$

The CEO also had to face competition. The advertisers were not happy with the still (semi-)secret status of its figures. Until the early eighties, the CESP continued to produce its own figures, which were totally incomparable with those of the CEO. The CEO measured audiences daily, with viewing diaries per quarters of hour, produced audiences by shows, quality indexes, and a host of secondary treatment of this rich data. The advertisers' body organized purely quantitative measurement three or four times a year, trying to reconstruct the previous day, and especially to provide audiences for advertising slots, with their social and demographic composition, and their distribution on the national territory. Each survey was based on different samples, different methods, different indicators and a different notion of the dissemination of results. While the CEO' surveys remained secret - although leaks were the most frequent in this period - the CESP's were shared with the whole advertising field.

In retrospect, this competition can also be analysed as a division of labour. The CESP's measures were the most important at the time, they slowly introduced a different way of thinking about television as a tool at the service of advertisers, which was still difficult to 'digest' for most public service broadcasters, and for 'their' measurers at the CEO. But this would not suffice when commercial broadcasters joined the fray: they had a shared interest with advertisers for a better, more consensual definition of the quantified audience, which would create agreement on its 'price' on what was now becoming a market. For that to happen, both systems would have to converge, not without jolts.

\section{The Audience as Market and the New Authority of the Interpreters: from the Mid-Eighties Onwards}

The time period between 1982 and 1987 was crucial for French broadcasting: two major laws were voted; a new independent regulatory authority, a private pay-TV channel and two private channels were created, and finally the first public channel was privatized in 1987. It is in this context that, in 1985, the former service of the Prime Minister's office

35 Jacques Durand, Interview, 6 February 1989. 
became a private company, controlled in the beginning by public capital almost entirely, then increasingly - but not exclusively - by private capital (meaning private or privatized television stations).

This company was named Médiamétrie. Its chair, for more than twenty years, was a woman, Jacqueline Aglietta. Having graduated from the ENSEA (the prestigious school of statistics and economic studies), Aglietta was competent in statistics and knowledgeable about the media as she had done some surveys while working at the SOFRES Opinion Poll Institute. Unlike Durand and in her own words, she had 'a taste for managing a business' - she had been the managing director of BVA, another poll institute, when she was recruited. She was also challenged by her mission to transform an administrative service into a private enterprise. ${ }^{36}$

Indeed, Aglietta had to add another kind of wizardry to the competence of the audience interpreters: she found herself negotiating between different people, different interests; in short, she was involved in the crucial task of building consensus which was at the heart of modern audience measurement in a competitive market. ${ }^{37}$ According to all witnesses, Aglietta was a master at this, often preparing major meetings based on individual encounters with each participant, so as to be better informed for her decision-making. She stayed true to her statistical background and recruited as her director general a well-known professor of statistics from the ENSEA, Philippe Tassi. She also had to convert a public service, with its very different rhythms, its deeply-rooted quiet habits, into a public company able to react quickly to the needs of its - increasingly private - shareholders. In the beginning, the advertising field considered Médiamétrie as 'an illusion, a creature of the state, financed by public actors, an appearance of liberalism. ${ }^{38}$

Aglietta would also have to regain control over television measurement, which had changed in 1982. Under pressure, and also aware of international developments, the CEO had started resorting to a panel equipped with audimeters (already a well-known technology, used in the US by Nielsen since the 1950s). This robot was able to 'spy' on the behaviour of viewers and it simply recorded and transmitted to which channel a set was tuned. This raised much interest, so much that on $31^{\text {st }}$ of March 1982, during the mid-day news programme on the second channel, Ragueneau and Durand, together with a representative of the Secodip, the company which was managing the sample, were invited on television to demonstrate how the audimat worked.

Médiamétrie realized however, that the CEO, which had initiated the change, only had nominal control over a system, which did not work well. The panel - or the actually effective panel - was smaller than claimed by SECODIP, some audimeters kept getting out of order and the advertisers considered the CESP figures, despite their scarcity, much more reliable. Ultimately the CESP set up its own panel with audimeters, despite the cost. Médiamétrie won the battle, not least because it had the support of the minister of communication, who was 'quite worried about having two sources of figures, one for private and one for public television, ${ }^{39}$ and from the start, wanted to make sure Médiamétrie would get a monopoly. In that sense, the creation of Médiamétrie in France in 1985 was similar to that of the Annan Report in the UK in 1977, which stated that audience measurement should be unified, a clause which led to the creation of the Broadcasters Audience Research Board (BARB) in 1982.40

But Médiamétrie also won the technical battle and made sure to adapt the 'product' to its 'clients,' by aiming from the start to ensure that the figures per household could be interpreted as individual audiences. The new system, called the Audimat+, started in 1985. Aglietta also used the ambiguity, which had weighed on the CEO, by positioning herself with a sure sense of timing and following her interlocutors - either as operator or as referee, either as private company or as public guarantor. In 1988, Médiamétrie became an autonomous private company. The State sold its shares, and the only remaining shareholders were the private and public television companies (1/3), the radio stations $(1 / 3)$, and the representatives of the advertising professions (1/3).

\footnotetext{
${ }^{36}$ Jacqueline Aglietta, Interview, 7 April 2004.

37 Jérôme Bourdon and Cécile Méadel, 'Introduction,' in Television Audiences Across the World. Deconstructing the Ratings Machines, Palgrave

Macmillan, 2014, p.20-21.

38 Jean Mauduit, Le Roman vrai de la mesure d'audience, Médiamétrie, 2005.

39 Aglietta, Interview.

40 Schwarzkopf, The Politics of enjoyment, p.47.
} 
In 1989, the Médiamat system was launched. The new system was based on peoplemeters, with a sui generis machine made by a local company according to the Médimatrie requirements. This took place as most of Western Europe, led by Germany, then Italy and the UK, had already chosen the peoplemeter. The peoplemeter was popularized on television, with at least one story on the main evening newscast on the $4^{\text {th }}$ of December 1988 and a full report of twenty minutes in prime time on a current affairs program on the $5^{\text {th }}$ of March 1992, entitled L'audimètre à bouton-poussoir. ${ }^{41}$ Finally, in 1993, a whole satirical program was devoted to audience measurement, named Ardimat, a combination of the name of its host, Ardisson, and the then popular Audimat. It didn't last, but this tells us how much audience measurement had become a public affair. In this excerpt, on a supposedly hypertechnological set, a pseudoexpert, looking at graphs on his computer, gives a parody of advice to a host, who goes out of the studio 'in the search of audimat.'

Médiamétrie, however, was also an arrangement typical of the French economy, in general, and of its audience interpreters, in particular. It is not either like Nielsen in the US, nor a JIC (joint industry committee) like the BARB in the UK or Auditel in Italy. It was rather a company, which was both commercial and incorporated the JIC, thus ensuring its monopoly and making it extremely hard for competition to emerge. This singularity showed in the profile of Aglietta's replacement: Bruno Chetaille, who was half private entrepreneur, half higher civil servant. A graduate of a grande école (the universities of the French élite), but with a modernist, commercial slant, HEC (Hautes Etudes Commerciales), he also had the mission of privatising TDF, the former public corporation in charge of transmission for terrestrial television: another kind of wizardry, which has got everything to do with the specific combination of market and state in the French economy, and little to do with audience statistics.

\section{Conclusion}

At any given time, one sees the need for audience assessment. This need however, is never governed only by one criterion, be it professional, commercial or political. We can distinguish several rationales, which still coexist with the dominant commercial one requiring instantly quantified audiences. When competition started (from the start for radio and much more slowly for television), audience measurement provided some form of 'parademocratic' legitimacy for radio and television stations. This need became more acute in the 1960s, as the cultural-pedagogical ambitions of public service became more difficult to achieve, and as entertainment gained ground, especially in prime time. Knowing what the people wanted, and proving it, started to become important for channel directors, who, in turn, needed audience measurers. For politicians, audience assessment was important when it became a criterion for policy-making. We saw this most clearly during the creation of Médiamétrie, but the whole story of the search for a quality index in the seventies was also an illustration of this process, even though it illustrated the failure of audience interpreters to deliver the goods to politicians.

What has changed is the methods of assessment, following the triple process we have analysed: quantification, externalization and increased visibility. Our small group started by accumulating variegated competences, mixing some form of (self-taught) statistics, marketing, opinion polls, social psychology, sociology, and even broadcasting production at different times. Slowly, all this coalesced into a new profession, with statistics taking central stage, accompanied by a focus on audience assessment per se - while necessarily giving up on any direct relation with the audience, except through the complex mediation of the technology at work, with the specific sample supposed to represent the audience.

Obviously, the commercial needs for audience measurement are central to the work of interpreters today, which gives them (or almost their production) a strong status, and much higher visibility than in the early days; they are

41 The pushbutton audiometer and the term 'peoplemeter' had not been adopted in French at the time. 
supposed to transform 'pairs of ears' into gold, as Smythe ${ }^{42}$ emphasized years ago. To achieve this, the amount of figures produced by a highly complex technological and statistical apparatus is staggering. But this must not hide the fact that the activity of audience interpretation, simultaneously performed through the flair of managers, through the various services of 'relations' with viewers, has always been central to television, for advertising or not. In all forms of TV market organisation, the audience interpreters have been (and still are) deeply involved in what could be called the production of audiences within media. The figures and tables are not the ultimate answer (although they are felt to be), they constitute only one form of language of interpretation which has always been rich and variegated (and was, to a certain extent, richer). Today, technology makes the results of this highly technological and 'scientific' work of interpretation, not only dominant, but present anytime, anywhere within media organizations.

\section{B i o graph y}

Jérôme Bourdon is Professor at the Department of Communications at Tel Aviv University and associate researcher with the Center for the Sociology of Innovation (CNRS/Ecole des Mines) in Paris. His research interests are: television history, international communication, media genres, collective memory. You can find a sample of publications and full CV here.

Cécile Méadel is Professor of Sociology at the Ecole des Mines de Paris and researcher at the Centre de Sociologie de l'Innovation (Mines-Paristech - CNRS). Her research interests are: regulation, technoregulation and selfregulation of communication technologies. Her latest books include: Jérôme Bourdon and C. Méadel (eds), Television Audiences across the World: Deconstructing the Ratings Machine, Basingstoke, Palgrave (forthcoming, 2014) and Éric Brousseau, Meryem Marzouki et Cécile Méadel (eds), Governance, Regulations and Power on the Internet, Cambridge University Press, 2012.

42 Dallas W. Smythe, 'On the Commodity Audience and Its Work,' in Dependency Road: Communications, Consciousness, Capitalism and Canada, Ablex, 1981, p. 22-51. 